\title{
The Role of Islamic Education in Social Change: A Case Study of the Elementary Schools of District Shaheed Benaz̄ir Bhuttū Abäd, Sindh
}

\author{
Mahboob Alì Dehräj \\ Assistant Professor, School of Education, Shaheed Benazir Bhutto \\ University, Sindh, Pākistān \\ Rameez Alì Māhesar \\ M. Phil Scholar at Media and Communication Studies, University of \\ Jāmshoro, Sindh, Pākistān
}

\section{Abstract:}

Päkistān came into being on the basis of two nation theory. There are number of subjects that are offered as compulsory at the secondary level of education. Islamic education is one of the subjects that is compulsory at school level in Pakistan. Being a religious subject for Muslim students studying in Pakistani schools, it is considered to be important in character building. In this study, an attempt has been made to analyze the effectiveness of Islamic education in the educational system and gauge students' perspectives on Islamic education as a character building tool. Survey method has been used to seek the objectives of the study. The population of the study includes students of secondary schools in District SBA. The Data has been collected through personal visits by giving questionnaires to students. The Percentage has been used in the analysis of the data. Major findings of the study suggest that Islamic education helps the students to become good citizen and plays a positive role as agents of social change in their local communities.

Keywords: Pakistān, Educational Reformation, Deformation, Isläm

\section{Introduction}

Islamic education is a compulsory subject in the educational system of Pakistan and is taught from primary level to higher classes. The subject consists of the vital information needed to maintain the Islamic faith and values. We cannot underestimate the its great impact on society. This subject enables Muslims to perform their religious duties and protect thier culture (Florida, 2014). Islamic education undoubtedly has a great impact on the learners' life and makes them very useful individuals for 
their society and moreover, this is helpful to learners in their learning process (Bengali, 1998).

Islamic education is playing a vital role in character building and makes the student realized their responsibilities in society. It also boost their confidence to face the problems and issues in their personal lives. (Jalindery, 2011). Above all the purpose of the creation of Pakistan was to live their lives according to the teachings of Islam. (Ziring, 1984). Interestingly, Pakistan was the first state which was created in the name of Islam. About $97 \%$ of the populations are Muslims and believe in the monotheism of Islam.

\section{Literature Review}

Ahmed \& Sharif (1963) say that the Educational Conference in 1947 decided that the education system in the newly born country would be based on Islamic teachings as it would be helpful in promoting and social unity in our Society. Noor Khan (1969) also emphasized the role of Islamic education in the creation of an ideological state and the country would be recognized by this identity among the nations in the world.

Arifa (2013) emphasizes that there is a need to work out in order to see for ourselves the effectiveness of this subject in our classes..

Govt. of Pakistan (1972) realized the importance of Islamic education and that is why it has been compulsory in secondary levels. Riaz (2014) writes that Islamic education is not meant to teach to the lower classes. But it needs to be made compulsory for all classes and our entire courses should be based on Islamic teaching.

Zaher (2012) says that Islamic study was made obligatory on all Muslim students in secondary and higher secondary level in order to promote unity and harmony among them as we can generate a devoted nation on the basis of Islamic ideology by imparting Islamic education and setting research goals.

Riaz (2014) says that Qur'ān Nāzira must stay obligatory and at the same time translation of the verses of the Holy Qur'ann with interpretation needs to be emphasized.

Arifa (2013) says that being Muslims we already have some basic knowledge of the Islam, so this should that Islamic study is not much a difficult subject as compare to chemistry, physics and other subjects. Students can learn and understand this subject in a very easy way.

Jālindery (2012) says that the teachers face difficulty when students lack basic knowledge of the Holy Quran and are not able to read/recite the Quran in a correct way. They are either shy or do not want to expose their 
shortcomings before teacher or other students. These types of students hide themselves behind clouds and take no interest in the classes and fell behind eventually.

Saād (1980) says that it (the subject) plays important role in character building. So this is a very good subject if teacher teaches it honestly with his heart and soul in the work having full command on the subject. It could change the nature of the students from bad things and force to pursue the right path.

\section{Advantage of Islamic education as a compulsory subject:}

1. This study or Islamic teachings will be helpful in understanding of Islam and pursuing Islamic life.

2. It will encourage the learners to adopt themselves to Islamic teachings and encourage others to practice it.

3. There is a dire need for adoption of Islamic system of education as other systems failed to serve the purpose. The study of Islam will boost up their character building and their love for entire humanity.

4. Islamic education will promote share of responsibilities in society and communal sacrifice eventually developing love for the human fellows.

5. This education also helps our community to love their country and take responsibilities on their shoulder.

\section{Statement of the Problem}

Though Islamic education is a compulsory subject in Pakistan and its role as a catalytic in character building cannot be ignored. Despite of its benefits Islamic education is given less priority as compared to other subjects in our institutions. This research will further look into students' perspective about Islamic education as a subject that builds character.

\section{Research Questions}

1. How much Islamic education is effective in educational system of Pakistan? 
UOCHJRS, Vol. (I), Issue (II)

2. What are the perspectives of students about Islamic education

in the context character building?

3. What are the challenges faced by the student in the learning of Islamic study at schools?

\section{Methodology}

This study is basically a Survey. Therefore questionnaires have been administrated as a tool of research. This study has limited to the students in government schools in District Shaheed Banazir Abad (SBB), Sindh, Pakistan. The population of the study is students of government school in District Shaheed Banzirabad Abad, Sindh, Pakistan.

\section{Sampling of the study}

The 300 students from government schools were selected randomly from the district SBB.

\section{Data Collection}

Data was collected from students of middle \& secondary boys \& girls schools of Talākā Dour Qāzi and Nawāb Shāh from district of Shaheed Benāzīr Abād, Sindh through questionnaires in quantitative way. In this research five point scales was used to collect the data from our schools.

\section{Data analyses}

The items of questionnaire have been analyzed as under:

Table 1: does Islamic education help student to increase their thrust of knowledge?

\begin{tabular}{|c|c|c|c|c|c|}
\hline \multicolumn{2}{|c|}{} & Frequency & Percentage & $\begin{array}{c}\text { Valid } \\
\text { Percentage }\end{array}$ & $\begin{array}{c}\text { Cumulative Valid } \\
\text { Percentage }\end{array}$ \\
\hline \multirow{4}{*}{ Valid } & Yes & 141 & 39.2 & 70.5 & 70.5 \\
\cline { 2 - 6 } & No & 45 & 12.5 & 22.5 & 93.0 \\
\cline { 2 - 6 } & $\begin{array}{c}\text { No } \\
\text { decision }\end{array}$ & 14 & 3.9 & 7.0 & 100.0 \\
\cline { 2 - 6 } & Total & 200 & 55.6 & 100.0 & \\
\hline
\end{tabular}

This data shows that most of the respondents agreed with the above statements. 
Table 2: Islamic education plays important role in character building of students.

\begin{tabular}{|c|c|c|c|c|c|}
\hline \multicolumn{2}{|c|}{} & Frequency & Percentage & $\begin{array}{c}\text { Valid } \\
\text { Percentage }\end{array}$ & $\begin{array}{c}\text { Cumulative } \\
\text { Valid } \\
\text { Percentage }\end{array}$ \\
\hline \multirow{4}{*}{ Valid } & Yes & 138 & 69.3 & 69.0 & 69.0 \\
\cline { 2 - 6 } & No & 43 & 21.5 & 21.5 & 90.5 \\
\cline { 2 - 6 } & No decision & 19 & 9.3 & 9.5 & 100.0 \\
\cline { 2 - 6 } & Total & 200 & $100, .0$ & 100.0 & \\
\hline
\end{tabular}

RESULT: This data shows that most of the respondents agreed with the above statement.

Table 3: Islamic education makes the students responsible to their society.

\begin{tabular}{|c|c|c|c|c|c|}
\hline \multicolumn{2}{|c|}{} & Frequency & percentage & $\begin{array}{c}\text { Valid } \\
\text { Percentage }\end{array}$ & $\begin{array}{c}\text { Cumulative } \\
\text { Valid } \\
\text { Percentage }\end{array}$ \\
\hline \multirow{3}{*}{ Valid } & Yes & 108 & 54.0 & 54.0 & 54.0 \\
\cline { 2 - 6 } & No & 89 & 44.5 & 44.5 & 98.5 \\
\cline { 2 - 6 } & No decision & 3 & 1.5 & 1.5 & 100.0 \\
\cline { 2 - 6 } & Total & 200 & 100.0 & 100.0 & \\
\hline
\end{tabular}

RESULT: This data shows that most of the respondents agreed with the above statement.

Table 4: Islamic education helps the students to become good citizens.

\begin{tabular}{|c|c|c|c|c|c|}
\hline \multicolumn{2}{|c|}{} & Frequency & Percentage & $\begin{array}{c}\text { Valid } \\
\text { Percentage }\end{array}$ & $\begin{array}{c}\text { Cumulative } \\
\text { Valid } \\
\text { Percentage }\end{array}$ \\
\hline \multirow{4}{*}{ Valid } & Yes & 142 & 71.0 & 71.0 & 71.0 \\
\cline { 2 - 6 } & No & 49 & 24.5 & 24.5 & 95.5 \\
\cline { 2 - 6 } & No decision & 9 & 4.5 & 4.5 & 100.0 \\
\cline { 2 - 6 } & Total & 200 & 100.0 & 100.0 & \\
\hline
\end{tabular}

RESULT: This data shows that most of the respondents agreed with the above statement. 
UOCHJRS, Vol. (I), Issue (II)

January-June, 2018

P 37

Table 5: Islamic education has a great impct on the social change of students.

\begin{tabular}{|c|c|c|c|c|c|}
\hline \multicolumn{2}{|c|}{} & Frequency & Percentage & $\begin{array}{c}\text { Valid } \\
\text { Percentage }\end{array}$ & $\begin{array}{c}\text { Cumulative } \\
\text { Percentage }\end{array}$ \\
\hline \multirow{3}{*}{ Valid } & Yes & 47 & 72.0 & 72.0 & 72.0 \\
\cline { 2 - 6 } & No & 144 & 23.5 & 23.5 & 95.5 \\
\cline { 2 - 6 } & No decision & 9 & 4.5 & 4.5 & 100.0 \\
\hline & Total & 200 & 100.0 & 100.0 & \\
\hline
\end{tabular}

RESULT: This data shows that most of the respondents agreed with the above statement.

Table 6: Islamic education enables students to face the challenges of life easily

\begin{tabular}{|c|c|c|c|c|c|}
\hline \multicolumn{2}{|c|}{} & Frequency & Percentage & $\begin{array}{c}\text { Valid } \\
\text { Percentage }\end{array}$ & $\begin{array}{c}\text { Cumulative } \\
\text { Valid } \\
\text { Percentage }\end{array}$ \\
\hline \multirow{3}{*}{ Valid } & Yes & 159 & 79.5 & 79.5 & 79.5 \\
\cline { 2 - 6 } & No & 33 & 16.5 & 16.5 & 96.0 \\
\cline { 2 - 6 } & No decision & 8 & 4.0 & 4.0 & 100.0 \\
\cline { 2 - 6 } & Total & 200 & 100.0 & 100.0 & \\
\hline
\end{tabular}

RESULT: This data shows that most of the respondents are agreed with the above statements.

Table 7: Classes of Islamite are mostly conducted in last period

\begin{tabular}{|c|c|c|c|c|c|}
\hline \multicolumn{2}{|c|}{} & $\begin{array}{c}\text { Frequenc } \\
\mathrm{y}\end{array}$ & Percentage & $\begin{array}{c}\text { Valid } \\
\text { Percentage }\end{array}$ & $\begin{array}{c}\text { Cumulative } \\
\text { Valid } \\
\text { Percentage }\end{array}$ \\
\hline \multirow{3}{*}{ Valid } & Yes & 144 & 72.0 & 72.0 & 72.0 \\
\cline { 2 - 6 } & No & 41 & 20.5 & 20.5 & 92.5 \\
\cline { 2 - 6 } & No decision & 15 & 7.5 & 7.5 & 100.0 \\
\cline { 2 - 6 } & Total & 200 & 100.0 & 100.0 & \\
\hline
\end{tabular}

RESULT: This data shows that most of the respondents agreed with the above statement. 
Table 8: Mostly students attend the classes of Islamic education

\begin{tabular}{|c|c|c|c|c|c|}
\hline \multicolumn{2}{|c|}{} & Frequency & Percentage & $\begin{array}{c}\text { Valid } \\
\text { Percentage }\end{array}$ & $\begin{array}{c}\text { Cumulative } \\
\text { Valid } \\
\text { Percentage }\end{array}$ \\
\hline \multirow{3}{*}{ Valid } & Yes & 161 & 80.5 & 80.5 & 80.5 \\
\cline { 2 - 6 } & No & 29 & 14.5 & 14.5 & 95.0 \\
\cline { 2 - 6 } & No decision & 10 & 5.0 & 5.0 & 100.0 \\
\cline { 2 - 6 } & Total & 200 & 100.0 & 100.0 & \\
\hline
\end{tabular}

RESULT: This data shows that most of the respondents agreed with the above statement.

Table 9: Classes of Islamic education are relegated by the administration

\begin{tabular}{|c|c|c|c|c|c|}
\hline \multicolumn{2}{|c|}{} & Frequency & Percentage & $\begin{array}{c}\text { Valid } \\
\text { Percentage }\end{array}$ & $\begin{array}{c}\text { Cumulative } \\
\text { Valid } \\
\text { Percentage }\end{array}$ \\
\hline \multirow{3}{*}{ Valid } & Yes & 148 & 41.1 & 74.0 & 74.0 \\
\cline { 2 - 6 } & No & 36 & 10.0 & 18.0 & 92.0 \\
\cline { 2 - 6 } & No decision & 16 & 4.4 & 8.0 & 100.0 \\
\cline { 2 - 6 } & Total & 200 & 55.6 & 100.0 & \\
\hline
\end{tabular}

RESULT: This data shows that most of the respondents agreed with the above statement.

Table 10: The students are only interested in this subject because marks are allocated to this subject in the entry tests.

\begin{tabular}{|c|c|c|c|c|c|}
\hline \multicolumn{2}{|c|}{} & Frequency & Percentage & $\begin{array}{c}\text { Valid } \\
\text { Percentage }\end{array}$ & $\begin{array}{c}\text { Cumulative } \\
\text { percentage }\end{array}$ \\
\hline \multirow{4}{*}{ Valid } & Yes & 144 & 72.0 & 72.0 & 72.0 \\
\cline { 2 - 6 } & No & 47 & 23.5 & 23.5 & 95.5 \\
\cline { 2 - 6 } & No decision & 9 & 4.5 & 4.5 & 100.0 \\
\cline { 2 - 6 } & Total & 200 & 100.0 & 100.0 & \\
\hline
\end{tabular}

RESULT: This data shows that most of the respondents agreed with the above statement. 
Table 11: Mostly student take it easy.

\begin{tabular}{|c|c|c|c|c|c|}
\hline \multicolumn{2}{|c|}{} & Frequency & percentage & $\begin{array}{c}\text { Valid } \\
\text { Percentage }\end{array}$ & $\begin{array}{c}\text { Cumulative } \\
\text { Percentage }\end{array}$ \\
\hline \multirow{4}{*}{ Valid } & Yes & 160 & 80.0 & 80.0 & 80.0 \\
\cline { 2 - 6 } & No & 31 & 15.5 & 15.5 & 95.5 \\
\cline { 2 - 6 } & No decision & 9 & 4.5 & 4.5 & 100.0 \\
\cline { 2 - 6 } & Total & 200 & 100.0 & 100.0 & \\
\hline
\end{tabular}

RESULT: This data shows that most of the respondents agreed with the above statement.

Table 12: Classes of Islamic education are mostly conducted in the last period.

\begin{tabular}{|c|c|c|c|c|c|}
\hline \multicolumn{2}{|c|}{} & Frequency & Percentage & $\begin{array}{c}\text { Valid } \\
\text { Percentage }\end{array}$ & $\begin{array}{c}\text { Cumulative } \\
\text { Valid } \\
\text { Percentage }\end{array}$ \\
\hline \multirow{3}{*}{ Valid } & Yes & 117 & 58.5 & 58.5 & 58.5 \\
\cline { 2 - 6 } & No & 66 & 33.0 & 33.0 & 91.5 \\
\cline { 2 - 6 } & No decision & 17 & 8.5 & 8.5 & 100.0 \\
\cline { 2 - 6 } & Total & 200 & 100.0 & 100.0 & \\
\hline
\end{tabular}

RESULT: This data shows that most of the respondents agreed with the above statement.

Table 13: Questions are not set on Islamic education in entry test, so students do not pay much attention on this subject

\begin{tabular}{|c|c|c|c|c|c|}
\hline \multicolumn{2}{|c|}{} & Frequency & Percentage & $\begin{array}{c}\text { Valid } \\
\text { Percentage }\end{array}$ & $\begin{array}{c}\text { Cumulative } \\
\text { Valid } \\
\text { Percentage }\end{array}$ \\
\hline \multirow{3}{*}{ Valid } & Yes & 167 & 83.5 & 83.5 & 83.5 \\
\cline { 2 - 6 } & No & 24 & 12.0 & 12.0 & 95.5 \\
\cline { 2 - 6 } & No decision & 9 & 4.5 & 4.5 & 100.0 \\
\cline { 2 - 6 } & Total & 200 & 100.0 & 100.0 & \\
\hline
\end{tabular}

RESULT: This data shows that most of the respondents agreed with the above statement. 
Table 14: Teachers of Islamic education show good manners.

\begin{tabular}{|c|c|c|c|c|c|}
\hline \multicolumn{2}{|c|}{} & Frequency & Percentage & $\begin{array}{c}\text { Valid } \\
\text { Percentage }\end{array}$ & $\begin{array}{c}\text { Cumulative } \\
\text { Valid } \\
\text { Percentage }\end{array}$ \\
\hline \multirow{3}{*}{ Valid } & Yes & 164 & 82.0 & 82.0 & 82.0 \\
\cline { 2 - 6 } & No & 30 & 15.0 & 15.0 & 97.0 \\
\cline { 2 - 6 } & No decision & 6 & 3.0 & 3.0 & 100.0 \\
\cline { 2 - 6 } & Total & 200 & 100.0 & 100.0 & \\
\hline
\end{tabular}

RESULT: This data shows that most of the respondents agreed with the above statement.

Table 15: Students are satisfied from the teacher's methodology

\begin{tabular}{|c|c|c|c|c|c|}
\hline \multicolumn{2}{|c|}{} & Frequency & Percentage & $\begin{array}{c}\text { Valid } \\
\text { Percentage }\end{array}$ & $\begin{array}{c}\text { Cumulative } \\
\text { Valid } \\
\text { Percentage }\end{array}$ \\
\hline \multirow{3}{*}{ Valid } & Yes & 166 & 83.0 & 83.0 & 83.0 \\
\cline { 2 - 6 } & No & 21 & 10.5 & 10.5 & 93.5 \\
\cline { 2 - 6 } & No decision & 13 & 6.5 & 6.5 & 100.0 \\
\cline { 2 - 6 } & Total & 200 & 100.0 & 100.0 & \\
\hline
\end{tabular}

RESULT: This data shows that most of the respondents agreed with the above statement.

Table 16: Students are interested because classes are conducted in on regular basis and in an appropriate manner.

\begin{tabular}{|c|c|c|c|c|c|}
\hline \multirow{7}{*}{} & Frequency & Percentage & $\begin{array}{c}\text { Valid } \\
\text { percentage }\end{array}$ & $\begin{array}{c}\text { Cumulative } \\
\text { Valid } \\
\text { Percentage }\end{array}$ \\
\hline \multirow{3}{*}{ Valid } & Yes & 162 & 81.0 & 81.0 & 81.0 \\
\cline { 2 - 6 } & No & 28 & 14.0 & 14.0 & 95.0 \\
\cline { 2 - 6 } & No decision & 10 & 5.0 & 5.0 & 100.0 \\
\cline { 2 - 6 } & Total & 200 & 100.0 & 100.0 & \\
\cline { 2 - 6 } & & & & & \\
\hline
\end{tabular}

RESULT: This data shows that most of the respondents agreed with the above statement. 
Table 17: A Teacher explains importance of Islamic education before the students

\begin{tabular}{|c|c|c|c|c|c|}
\hline \multicolumn{2}{|c|}{} & Frequency & Percentage & $\begin{array}{c}\text { Valid } \\
\text { Percentage }\end{array}$ & $\begin{array}{c}\text { Cumulative } \\
\text { Valid } \\
\text { Percentage }\end{array}$ \\
\hline \multirow{3}{*}{ Valid } & Yes & 170 & 85.0 & 85.0 & 85.0 \\
\cline { 2 - 6 } & No & 22 & 11.0 & 11.0 & 96.0 \\
\cline { 2 - 6 } & No decision & 8 & 4.0 & 4.0 & 100.0 \\
\cline { 2 - 6 } & Total & 200 & 100.0 & 100.0 & \\
\hline
\end{tabular}

RESULT: This data shows that most of the respondents agreed with the above statement.

Table 18: Students already have some much knowledge so they are over confident about this subject.

\begin{tabular}{|c|c|c|c|c|c|}
\hline \multicolumn{2}{|c|}{} & Frequency & Percentage & $\begin{array}{c}\text { Valid } \\
\text { Percentage }\end{array}$ & $\begin{array}{c}\text { Cumulative } \\
\text { Valid } \\
\text { Percentage }\end{array}$ \\
\hline \multirow{3}{*}{ Valid } & Yes & 173 & 86.5 & 86.5 & 86.5 \\
\cline { 2 - 6 } & No & 16 & 8.0 & 8.0 & 94.5 \\
\cline { 2 - 6 } & No decision & 11 & 5.5 & 5.5 & 100.0 \\
\cline { 2 - 6 } & Total & 200 & 100.0 & 100.0 & \\
\hline
\end{tabular}

RESULT: This data shows that most of the respondents agreed with the above statement.

Table 19: Students consider it easy so they give it much importance.

\begin{tabular}{|c|c|c|c|c|c|}
\hline \multicolumn{2}{|c|}{} & Frequency & Percentage & $\begin{array}{c}\text { Valid } \\
\text { Percentage }\end{array}$ & $\begin{array}{c}\text { Cumulative } \\
\text { Valid } \\
\text { Percentage }\end{array}$ \\
\hline \multirow{3}{*}{ Valid } & Yes & 100 & 50.0 & 50.0 & 50.0 \\
\cline { 2 - 6 } & No & 81 & 40.5 & 40.5 & 90.5 \\
\cline { 2 - 6 } & No decision & 19 & 9.5 & 9.5 & 100.0 \\
\cline { 2 - 6 } & Total & 200 & 100.0 & 100.0 & \\
\cline { 2 - 6 } & & & & & \\
\hline
\end{tabular}

RESULT: This data shows that most of the respondents agreed with the above statement. 


\section{Discussion of tables and Findings:}

1. Most of the students agreed that classes allocated for Islamic education need to be given preference.

2. Most of the students agreed that Islamic education helps students to increase their thrust for knowledge.

3. Most of the students agreed that Islamic education plays important role in character building of students.

4. Most of the students agreed that Islamic education makes the students responsible to their society.

5. Most of the students agreed that Islamic education help the students to become a good citizen.

6. Most of the students agree that Islamic education has a great impact on the social change of students.

7. Most of the students agreed that Islamic study enables students to face the challenges of life easily

8. Most of the students agreed that Classes of Islamic study are mostly conducted in the last period.

9. Most of the students agreed that Mostly students do not attend the classes of Islamic education.

10. Most of the students agreed that Classes of Islamic education are relegated by the administration.

11. Majority of the students agreed that the subject allocated marks in entry tests, so students are interested in this subject.

12. Greater number of the students agreed that Mostly student take it easy.

13. Greater number of students agreed that the teachers of Islamic education display good manners.

14. Majority of the students agreed that Students are satisfied with their teacher's methodology.

15. Highest number of the students agreed that Students are interested because classes are conducted in the last period.

16. Most of the students agreed that the teacher explains importance of Islamic education before the students.

17. Most of the students agreed that Students have already much knowledge so they are over confident about this subject.

\section{Recommendations}

It is not enough to make Islamic education compulsory but there are a range of steps that are to be taken in the light of the above findings. These are given as under:

1. Teachers should assign different responsibilities to the students keeping in mind the teachings of Islamic education and 
observe them whether they are following those teachings of Islamic education in their practical life or not.

2. The teachers of Islamic education need to work hard on the cultivation of minds of student to face the challenges of daily life.

3. Classes of Islamic education should be conducted in earlier in the day.

4. Teachers should take attendance of the classes and make his lecture more interesting.

5. This subject should be included in every entry test so that students consider it an important subject.

6. Teachers of Islamic education should display good manners as Islamic model teacher.

7. Teachers of Islamic education should be trained on modern lines and develop their teaching methodology

\section{References}

1. Agy, M. S. F. A., Oliveira, R. L., Ribeiro, C. V. D. M., Ribeiro, M. D., Bagaldo, A. R., Araújo, G. G. L. D., ... \& Ribeiro, R. D. X. (2012). Sunflower cake from biodiesel production fed to crossbred Boer kids. Revista Brasileira de Zootecnia, 41(1), 123-130.

2. Ahmed, M., \& Sharif, S. M. (1963). Islamic Aspects of the New Constitution of Pakistan. Islamic Studies, 2(2), 249-286

3. Aijola, A. (2006). Introduction to Islamic law. Adam Publishers

4. Ali, S. (2006). Why does policy fail? Understanding the problems of policy implementation in Pakistan-a neurocognitive perspective. International Studies in Educational Administration, 34(1)

5. Cochrane, I. (2009). The Causes of the Bangladesh War. Lulu. com.

6. Florida, R. (2014). The Rise of the Creative Class--Revisited: Revised and Expanded. Basic Books (AZ).

7. Jacobson, J. (2006). Islam in transition: religion and identity among British Pakistani youth. Routledge.

8. Jalundery (2013) wafaqul importance of Islamic education madders madaeris mulatan vol $5 \mathrm{p}, 5$

9. Khan, W. N., Lodhi, M. A., Ali, I., Azhar-Ul-Haq, Malik, A. Bilal, S. \& Choudhary, M. I. (2006). New natural urease inhibitors from Ranunculus repen. Journal of enzyme inhibition and medicinal chemistry, 21(1), 17-19. 
10. Perveen, T. (2003). Evaluation of Islamite Compulsory for 8th Class prescribed by Textbook

11. Riaz, S. (2014). The Educational System in Pakistan and the Place of Islamic Schooling. In New Islamic Schools (pp. 4986). Palgrave Macmillan US.

12. Saad, G. (1980). Selected Bibliography and Abstracts of Educational Materials in Pakistan. Volume 14, No. 2, 1980. Period Covered April-June 1980.

13. Ziring, L. (1984). From Islamic Republic to Islamic State in Pakistan.

@ 2017 by the author, Licensee University of Chitral, Journal of Religious Studies. This article is an open access article distributed under the terms and conditions of the Creative Commons Attribution (CC BY) (http://creativecommons.org/licenses/by/4.0/). 